\title{
Factors related to adherence to treatment for systemic hypertension
}

\author{
Fatores relacionados à adesão ao tratamento da hipertensão arterial sistêmica
}

\author{
Factores relacionados a la adhesión al tratamiento de la hipertensión arterial sistémica
}

Silvana Maria Coelho Leite Fava ${ }^{1}$, Eliana Cavalari Teraoka ${ }^{2}$, Amanda dos Santos Oliveira ${ }^{2}$, Amanda Aparecida Teixeira Ferreira Calixto ${ }^{2}$, Letícia Palota Eid², Eugênia Velludo Veiga ${ }^{2}$

This study aimed to seek the evidence available in the literature regarding the factors related to adherence to treatment for systemic hypertension. It used the method of integrative review in the databases MEDLINE, CINAHL, and LILACS, using the keywords: hypertension, compliance, non-compliance, adherence, non-adherence, patient compliance, in the period 2004-2008, and articles in Portuguese, English and Spanish, with the use of a validated instrument and content analysis. 28 studies were selected, $64.3 \%$ of which had level of evidence VI. The following were identified as factors related to adherence to treatment: treatment costs, educational activities, sex, physician-patient relationship, physiological and behavioral aspects, drug therapy, attending checkups and lifestyle. The use of combined strategies is suggested in order to increase the individuals' adherence to the treatment. Gaps point to the valorization of dialogic relationships for integrated and more efficacious health practices.

Descriptors: Patient Compliance; Medication Adherence; Hypertension; Guideline Adherence.

Objetivou-se buscar as evidências disponíveis na literatura sobre os fatores relacionados à adesão ao tratamento da hipertensão arterial sistêmica. Adotou-se método da revisão integrativa nas bases de dados MEDLINE, CINAHL, LILACS, com as palavras chave: hypertension, compliance, non compliance, adherence, non adherence, patient compliance, no período entre 2004-2008, artigos nos idiomas português, inglês e espanhol, com o uso de instrumento validado e a análise de conteúdo. Selecionou-se 28 estudos, 64,3\% com nível de evidência VI. Identificaram-se como fatores relacionados à adesão ao tratamento: custos do tratamento, atividades educacionais, gênero, relação médico-paciente, aspectos fisiológicos, comportamentais, terapêutica medicamentosa, frequência às consultas e estilo de vida. Sugere-se o uso de estratégias combinadas, para aumentar a adesão ao tratamento dos indivíduos. Lacunas apontam para a valorização das relações dialógicas para práticas em saúde integradas e mais eficazes.

Descritores: Cooperação do Paciente; Adesão à Medicação; Hipertensão; Fidelidade a Diretrizes.

El objetivo fue buscar las evidencias disponibles en la literatura acerca de los factores relacionados con la adherencia al tratamiento de la hipertensión. Se adoptó el método de revisión integradora en las bases de datos: MEDLINE, CINAHL y LILACS, con las palabras clave: hypertension, compliance, non compliance, adherence, non adherence, patient compliance, de 2004-2008 en portugués, inglés y español, con el instrumento validado y análisis de contenido. Se encontraron 28 estudios: $64,3 \%$ con nivel de evidencia VI. Se observaron los siguientes factores relacionados a la adhesión al tratamiento: costos del tratamiento, actividades educativas, género, relación médico paciente, aspectos fisiológicos y conductuales, tratamiento medicamentoso, frecuencia de consulta y forma de vida. Se sugiere uso de estrategias combinadas para intensificar la adhesión al tratamiento de los individuos. Brechas señalan para valoración de las relaciones dialógicas para prácticas en salud integral y más eficaz.

Descriptores: Cooperación del Paciente; Cumplimiento de la Medicación; Hipertensión; Adhesión a Directriz.

\footnotetext{
${ }^{1}$ Universidade Federal de Alfenas. Alfenas, MG, Brazil.

${ }^{2}$ Escola de Enfermagem de Ribeirão Preto, Universidade de São Paulo. Ribeirão Preto, SP, Brazil.

Corresponding author: Eugênia Velludo Veiga

Av. Bandeirantes, 3900, Campus Universitário, Ribeirão Preto, SP, Brazil. CEP: 14040-902. E-mail: evveiga@eerp.usp.br
} 


\section{Introduction}

The concern about adherence to treatment for Systemic Hypertension ( $\mathrm{SH}$ ) is due to the significant prevalence of this disease, and to its chronic and asymptomatic character; to the serious complications resulting from high blood pressure levels ${ }^{(1)}$; to the permanent disabilities caused; to people having to take early retirement, and to the high cost of the treatment and inpatient treatment, both for the person with $\mathrm{SH}$, and for the health and social security systems ${ }^{(2-3)}$.

Adherence to the treatment for SH corresponds to the degree of agreement between the medical prescription and advice and the client's behavior, which is a great challenge ${ }^{(4)}$; it is a complex process, and the patients' decisions on how to manage the taking of their medications are probably based on economic, physical, psychological and social considerations ${ }^{(5)}$.

It is a process subject to the influence of multiple factors which may determine the client's behavior in relation to the recommendations regarding the treatment for SH. These factors are related to the person, such as personal and social conditions; to the disease, its chronicity and its asymptomatic character; to the characteristics of the therapeutic program: cost, number of doses, and the adverse effects of the medications; to the relationship between client and health professional and to the difficulties encountered in accessing the health system ${ }^{(4-7)}$.

The multiple dimensions involved in adherence to the treatment allow us to recognize that the regular monitoring of people with $\mathrm{SH}$, motivating them to adherence to the drug- and non-drug treatment, remains a great challenge for the health team, principally for the nurses.

In this aspect, the nursing consultation represents an important instrument for encouraging the adherence and for monitoring people with SH, as qualified listening allows openness to dialog, the clarification of doubts, concerns and the reasons which stop people from being ready for change. In understanding these reasons, the nurse can help to discover the potential benefits of the change of lifestyle from the patients' point of view ${ }^{(8)}$, allowing her to agree goals with them and plans of how to follow the care ${ }^{(9)}$.

In the light of the complexity of the issue, this study aimed to seek and analyze the scientific evidence regarding the factors related to adherence to treatment for SH, in the period 2004-2008.

\section{Method}

In order to achieve the objective proposed, the method of the integrative review was chosen ${ }^{(10)}$. The following stages were undertaken: selection of the research question, establishment of inclusion and exclusion criteria, categorization and evaluation of the articles included in the review, and interpretation and presentation of the results, so as to answer the following guiding question: "What is the evidence available in the literature regarding the factors related to adherence to treatment for SH?" The data search was undertaken in August 2009. For selecting the studies, the following databases, important in the context of health and available online were used: MEDLINE (Medical Literature Analysis and Retrieval Sistem on-line), CINAHL (Cumulative Index to Nursing and Allied Health Literature) and LILACS (Latin American and Caribbean Literature on Health and Science). The inclusion criteria were: articles published and available online, in full text, free of charge, in Portuguese, English and Spanish, in the period $2004-2008$, adults over 18 years old, using the keywords: hypertension, compliance, noncompliance, adherence, non-adherence, and patient compliance; and which mentioned the factors related to adherence to the treatment. An evaluation of the articles was undertaken by four reviewers, the results being compared later, so as to ascertain that the articles met the inclusion criteria.

The exclusion criteria used were: articles repeated in the databases consulted, these being counted only once for analysis; those which did not 
present the text in full; those which addressed the issue of adherence to the treatment, but which did not mention the factors influencing adherence; those which aimed to compare drugs, which presented the advantages of specific pharmacological treatments, and those which sought to evaluate the efficacy of biological markers.

In the three databases, 1178 articles were found, using the combination of the keywords "hypertension and compliance"; "hypertension and non-compliance"; "hypertension and non compliance"; "hypertension and adherence"; "hypertension and non-adherence"; "hypertension and non adherence"; and "hypertension and patient compliance", of which 790 were in the MEDLINE database, 231 in CINAHL and 157 in LILACS; of these, 1110 were available in full and free of charge. 68 articles from LILACS were excluded, as they were not available free of charge for consultation.

In a first analysis, through the reading of the title and the abstracts of the 1110 articles, 199 articles were selected, 911 articles being excluded (56 from LILACS, 657 from MEDLINE and 198 from CINAHL), due to the issue and repetition in the databases; in a second analysis, through the reading of the articles in full, 28 articles were selected which responded to the study's guiding question; of these, 22 (78.6\%) were selected from the MEDLINE database, and 6 (21.4\%) from CINAHL.

For data collection, a validated instrument elaborated was used ${ }^{(10)}$, covering the identification of the article, methodological characteristics, evaluation of the methodological rigor, interventions measured, results found and conclusion and/or considerations.

For the analysis of the studies' levels of evidence $^{(11)}$, the following criteria were adopted: level I: resulting from controlled studies or originating from clinical guidelines based in systematic reviews of controlled randomized clinical trials; level II, resulting from well-designed randomized controlled clinical trials; level III, resulting from well-designed non-randomized clinical trials; level IV, originating from well-designed case control or cohort studies; level $\mathrm{V}$, original evidence from systematic reviews of descriptive and qualitative studies; level of evidence VI, originating from descriptive and qualitative studies; level VII, evidence originating from the opinion of authorities and/or reports from a committee of specialists.

After the reading, the three stages proposed by the authors were undertaken, namely: Pre-analysis: in this stage, skim reading of the articles was undertaken; Exploration of the material: the information contained in the material was codified, that is, excerpts were taken from the text seeking to classify the excerpts referred to in thematic categories; Treatment of the results and interpretation: the data were extracted and analyzed using descriptive statistics and content analysis ${ }^{(12)}$, and grouped, in the way in which the factors related to adherence to the treatment were presented and conceived, so as to constitute the thematic categories. The thematic categories were related to both the studies' objectives and results.

\section{Results}

Of the 28 studies analyzed, $21(75 \%)$ were undertaken in the United States; five $(17.8 \%)$ in Canada and two (7.1\%) in Brazil; 26 (92.8\%) articles were published in English.

Regarding the studies' methodology, 27 (96.4\%) were undertaken with a quantitative approach and one $(3.6 \%)$ was qualitative. Among the quantitative studies, $23(85.1 \%)$ presented a non-experimental design, two (7.1\%) an experimental design, and two (7.1\%) a quasi-experimental design. The samples were by convenience in 18 (66.6\%) studies and randomized in nine (33.3\%). In relation to the study with a qualitative approach, the theoretical framework was not mentioned, and its method of study was the focus group technique, and content analysis.

The articles were predominantly published in 2007, with $21(75 \%)$, and $5(17.7 \%)$ in 2008; the majority, 26 (92.8\%) was published in journals of 
the other areas of health, apart from nursing. The authors' academic background was described only in 2 (7.14\%) studies.

Regarding the studies' level of evidence ${ }^{(13)}, 18$ $(64.3 \%)$ were identified with level of evidence VI, originating from descriptive and qualitative studies, followed by 5 (17.8\%) with level II, resulting from well-designed randomized controlled clinical trials; 4 $(14.3 \%)$ with level IV, originating from well-designed case control or cohort studies and 1 (3.6\%) with level III, resulting from a well-designed nonrandomized clinical trial.

The studies' objectives were grouped in the following thematic categories: strategies for evaluating the adherence to the treatment in 8 (28.6\%); the relationship between adherence to the treatment and control of blood pressure (BP) in 5 (17.8\%); factors hindering adherence in $4(14.3 \%)$; factors facilitating adherence in 3 (10.7\%); treatment costs in $3(10.7 \%)$; the adherence to the treatment related to the attendance of medical appointments in 3 (10.7\%); adherence to drug treatment in 2 (7.1\%); adherence and educational level in 1 (3.6\%); and adherence and sex in 2 (7.1\%) studies.

In relation to the dependent variable investigated, $18(66.6 \%)$ adopted adherence to the treatment; 4 (14.8\%), the BP levels; 3 (11.1\%), these two variables simultaneously and $2(7.4 \%)$ the BP levels and the use of the medication.

The independent variables adopted in the studies were: 7 (25.9\%) used the use of the educational strategies for increasing adherence; 5 (18.5\%), the individuals' demographic characteristics; 2 (7.4\%), the BP levels; 2 (7.4\%) the beliefs about the disease; and, in the other studies: the relationship between age, sex, use of an adherence measurement scale, the adverse effects of the medications, the use of messaging the patient using a cell phone, the use of blood monitoring of the medication, evaluation of knowledge and behavior in relation to the disease, cost of the medications and the follow-up attendance at the medical appointments.
The studies' results were grouped in the following thematic categories: adherence and control of BP; adherence and use of the medications; adherence and educational level; adherence and attendance at medical appointments; adherence and sex; adherence and strategies used; hindering or facilitating factors which influenced adherence; use of antihypertensive drugs and control of BP and treatment costs.

The category of treatment costs was discussed in $3(11.1 \%)$ studies, in two of which the low cost of the medication contributed to the adherence ${ }^{(14-15)}$. Adherence and control of BP were the object of 4 (14.8\%) studies, of which in three, there was no statistical relationship between adherence and the control of BP.

The use of antihypertensive drugs was related to the control of BP in 1 (3.7\%) study; and the association between adherence and the use of medication was addressed in 2 (7.4\%) studies, with the class of diuretics being responsible for the lowest adherence.

Adherence to the treatment was associated with different variables. Among these was a positive relationship with educational level in 1 (3.6\%) study, which revealed that the higher the educational level, the greater the adherence; regarding sex, 2 (7.4\%) studies revealed that adherence to the treatment was greater among males; the attendance at medical appointments favored adherence in $2(7.4 \%)$ studies and in $1(3.6 \%)$ study did not influence the control of blood pressure levels. It was also noted that the greater the length of the treatment, the lower the rate of adherence ${ }^{(16)}$.

In relation to the strategies adopted for evaluating adherence to the treatment, 8 (29.6\%) studies used them, these being: the use of a plasma marker; educational activities regarding the pathology, healthy eating, undertaking physical activity and the modifiable risk factors for the disease. It was ascertained that four studies addressed the importance of social support and guidance in the correct use of the medications, it being the case that 
these strategies were shown to be efficacious; the other four studies used guidance strategies by means of the telephone, support from nurses, guidance through video and leaflets and the counting of tablets using electronic monitoring; however, these strategies were not shown to be effective in raising the rate of adherence to treatment for $\mathrm{SH}$.

The strategy of nursing support for increasing adherence was not shown to be effective in a randomized study ${ }^{(17)}$, in which the intervention group received monitoring and support from nurses, the electronic monitoring of medication counts and the measuring of BP levels over six months of study, while the control group received electronic monitoring of medication counts and measuring of BP.

For the evaluation of the use of the medications, one efficacious strategy used was the use of the plasma marker; however, in the light of the method's high complexity, the factors of its high cost and sideeffects, such as weight gain, could hinder its use as a routine method of evaluating adherence ${ }^{(18)}$.

Among the factors which facilitate adherence to the treatment, the following were identified: knowledge about $\mathrm{SH}$, the practice of self-care, and social support, which were cited in 3 (10.7\%) studies. The factors which hindered adherence were presented in $3(10.7 \%)$ studies and were related to the changes in eating habits and lifestyle, disbelief in the disease, the side-effects of the medications, the non-control of the BP and a catastrophic environmental event which occurred in the period.

The limiting factors of the studies analyzed were related to the criteria for defining the sample, such as inadequate size, specific samples which made it difficult to generalise the application of the results to other scenarios, convenience samples and bias in sample selection. It was also ascertained that $13(46.4 \%)$ studies presented confounding factors among the variables studied, such as: not taking into account the phenomenon of white coat hypertension; self-reporting regarding lifestyle and adherence; obtaining data from secondary sources; the data collection instrument not being directly administered to the person, but rather to a family member; failure to monitor the subject with $\mathrm{SH}$ in the long term for evaluating adherence; the rates of adherence being self-reported, which could overestimate it in relation to electronic monitoring, and use of the mean of the $\mathrm{BP}$ in recent years, as well as the measuring of $\mathrm{BP}$ with a non-standardized technique.

The studies' recommendations point to the need to understand the clients' needs, to have knowledge about the current guidelines for treatment of SH, to implement comprehensive treatment, to encourage self-care in the clients, and to promote access to the medications.

For the evaluation of the adherence to the treatment, the studies suggest: use of reliable measurements for its evaluation; the undertaking of longitudinal studies; not measuring it by attendance at medical appointments and not associating it only with the controlled pressure levels.

Among the recommendations for increasing adherencetothetreatment, the authors emphasizethat, alone, no intervention was shown to be efficacious; and they suggested the combination of various strategies: appropriate information, counselling, self-monitoring, use of reminders, periodical encouragement, family therapy, psychotherapy, monitoring by telephone, and other ways applicable for each case ${ }^{(19)}$.

The studies analyzed concluded that many factors influenced individuals' adherence to the treatment, among which one finds: costs, side-effects and quantity of medications; the type of relationship between the health professional and the client; social, behavioral and cultural factors involved; sex; attendance at medical appointments; lifestyle; and the presence or not of educational activities and programs.

\section{Discussion}

It may be inferred that the studies' objectives prioritized the use of strategies for evaluating the 
adherence to the treatment for $\mathrm{SH}$; the relationship between the adherence and the control of the BP; and investigation of the factors which hindered adherence to the treatment.

The evaluation of the adherence to the drug treatment is one of the difficulties which health professionals face, perhaps due to the absence of appropriate instruments for validating the therapeutic measures, as the guarantee of the accuracy and reliability of the results obtained is a crucial point in this $\operatorname{process}^{(20)}$.

Thus, some authors ${ }^{(16)}$ indicate that the adherence to the treatment for SH cannot be measured only by the control of the blood pressure levels, as there are other variables, such as dosages, pharmacological classes, presence of comorbidities, and emotional factors which also contribute to the ineffective control of the blood pressure levels.

Accordingly, for evaluation of the adherence to treatment, the following are recommended: the occurrence of inpatient treatment and comorbidities; the direct indicators, through the biological markers of urine and blood, and weight loss; the indirect indicators, such as counting of tablets; the subjective reports of patients or of other persons; the use of the health network, such as attending appointments and the use of preventive services ${ }^{(21)}$.

Among the factors related to normal adherence to drug treatment, the following stand out: the cost of medications, and the difficulty in accessing the public system ${ }^{(22)}$, which constitutes a relevant aspect in the planning of public policies and in health care. Access to the medication is an indicator of the quality and resolutive capacity of the health system and is an important determinant in the following of the treatment prescribed ${ }^{(23)}$.

The identification of factors which determine the individual's non-adherence to the treatment is of extreme importance in the administration of the therapeutic strategy and in the obtaining of satisfactory results for achieving adherence ${ }^{(22)}$.

Regarding the factors which facilitate adherence to the treatment, knowledge regarding $\mathrm{SH}$, the practice of self-care, and social support stand out. Thus, emphasis is placed on the crucial role of nursing for adherence, as a strategy centered in health education which allows the implementation of the care by the service users ${ }^{(24)}$.

Through critical reflection, the nurse can relate the theory to the practice context and, thus, can have dialogs with the service user in which the needs for self-care, as well as the subject's capabilities, become evident $^{(24)}$.

The improvement of the adherence to the treatment can be achieved if the implementation of the care is based on the person's needs and degree of risk, and on her capacity for adherence, and motivation for self-care in each consultation ${ }^{(9)}$.

Thus, the adherence to the treatment is not restricted only to the prescription of a medication or conducts. This following of the treatment depends much more on the fact of the clinical practice not focusing on the health professionals and being centered on the person, a fundamental principle of family and community medicine ${ }^{(25)}$.

\section{Conclusion}

Adherence to treatment for $\mathrm{SH}$, for the people with $\mathrm{SH}$ and for health professionals alike, is a challenge; this is because, in this process, different dimensions are compromised - as a result of the factors related to the person, to the health services, to the disease, and to the treatment - which deserve a different perspective and work with resolutive capacity of a multi-professional team. These dimensions permeate the experience of life and the subjectivity in the process of being ill and uniquely influence the way of thinking, of acting, and of seeking the treatment and the cure in the health services.

The studies analyzed indicate that the educational strategies, when combined, and the valorization of the relationship between the health professional and the client, are decisive actions for 
increasing adherence to the treatment on the part of the individual with $\mathrm{SH}$.

However, the evaluation of the adherence to the treatment by attendance at clinical appointments or through the control of the individuals' blood pressure levels were not presented as useful strategies.

In the light of this, the gaps point to the important role of the health professionals, in conjunction with the empowerment of the person with $\mathrm{SH}$ for optimizing the adherence to the treatment. These professionals' actions must privilege a dialogic, rather than prescriptive, relationship; and must value and consider the persons with $\mathrm{SH}$ as endowed with unique characteristics and potential, it being necessary to investigate their historical, social and cultural context in order to provide comprehensive health care which meets the individual needs.

This study's limitations refer to the search period of the articles published over four years, the consultation in only three databases, and the use of keywords. The undertaking of further studies with greater coverage in the search period for the articles' publication, the extending of the number of databases, and the use of indexed descriptors is suggested.

\section{Acknowledgements}

We would like to thank Professor Dr. Maria Suely Nogueira for the conception and encouragement of the work undertaken, and the Research Group: Workshop for Projects in Sphygmomanometry, of the Ribeirão Preto School of Nursing, of the University of São Paulo, for the opportunity for group learning.

\section{Collaborations}

Fava SMCL, Teraoka EC and VeigaEV contributed to the conception, analysis and interpretation of the data, editing of the article and final approval of the version to be published. Oliveira AS, Calixto AATF and Eid LP contributed to the conception of the work, data collection, analysis and interpretation of the data, and editing of the article.

\section{References}

1. Fortes AN, Lopes MVO. Análise dos fatores que interferem no controle da pressão arterial de pessoas acompanhadas numa unidade básica de atenção à saúde da família. Texto Contexto Enferm. 2004; 13(1):26-34.

2. Lessa I. Impacto social da não-adesão ao tratamento da hipertensão arterial. Rev Bras Hipertens. 2006; 13(1):51-4.

3. Marinker M, Shaw J. Not to be taken as directed: putting concordance for taking medicines into practice. BMJ. 2003; 326(7385):348-9.

4. Leite SN, Vasconcellos MPC. Adesão à terapêutica medicamentosa: elementos para a discussão de conceitos e pressupostos adotados na literatura. Ciênc Saúde Coletiva. 2003; 8(3):775-82.

5. Krousel-Wood M, Thomas S, Muntner P, Morisky D. Medication adherence: a key factor in achieving blood pressure control and good clinical outcomes in hypertensive patients. Curr Opin Cardiol. 2004; 19(4):357-62.

6. Osterberg L, Blaschke T. Adherence to medication. N Engl J Med. 2005; 353(5):487-97.

7. Vermeire E, Hearnshaw H, Van Royen P, Denekens J. Patient adherence to treatment: three decades of research a comprehensive review. J Clin Pharm Ther. 2001; 26(5):331-45.

8. Zuckoff A. "Why won't my patients do what's good for them?" Motivational interviewing and treatment adherence. Surg Obes Relat Dis. 2012; 8(5):514-21.

9. Ministério da Saúde (BR). Secretaria de Atenção à Saúde. Departamento de Atenção Básica. Estratégias para o cuidado da pessoa com doença crônica: hipertensão arterial sistêmica. Brasília: Ministério da Saúde; 2013.

10. Whittemore R, Knafl K. A revisão integrativa: metodologia atualizada. J Adv Nurs. 2005; 52(5): 546-53.

11. Ursi ES, Galvão CM. Prevenção de lesões de pele no perioperatório: revisão integrativa da literatura. Rev Latino-Am Enfermagem. 2006; 14(1):124-31.

12. Bardin L. Análise de conteúdo. Lisboa: Edições 70; 2009.

13. Melnyk BM, Fineout-Overholt E. Making the 
case for evidence-based practice. In: Melnyk BM, Fineout-Overholt E, editors. Evidence-based practice in nursing and healthcare: a guide to best practice. Philadelphia: Lippincot Williams \& Wilkins; 2005. p.3-24.

14. Taira DA, Wong KS, Tamas FF, Chung RS. Copayment level and compliance with antihypertensive medication: analysis and policy implications for managed care. Am J Manag Care. 2006; 12(11):678-83.

15. Buabeng KO, Matowe L, Plange-Rhule J. Unaffordable drug prices: a major cause of noncompliance with hypertension medication in Ghana. J Pharm Pharmaceut Sci. 2004; 7(3):350-2.

16. Shah ND, Steiner ME, Vermeulen LC, Fleming LA, Cory PR. The role of medication adherence as a determinant of blood pressure control in a managed care population. Dis Manage Healt Outcomes. 2007; 15(4):249-56.

17. Schroeder K, Fahey T, Hollinghurst S, Peters TJ. Nurse-led adherence support in hypertension: a randomized controlled trial. Fam Pract. 2005; 22(2):144-51.

18. Braam RL, Uum SHMV, Lenders JWM, Thien T. Bromide as marker for drug adherence in hypertensive patients. Br J Clin Pharmacol. 2008; 39(5):733-6.

19. Haynes RB, Ackloo E, Sahota N, McDonald HP, Yao X. Interventions for enhancing medication adherence. Cochrane Database Syst Rev. [periódico na Internet]. 2008 [cited 2008 oct 8]; 16(2): [10 p]. Available from: http://www.cochrane.org/ reviews/en/ab000011.html
20. Borba AKOT, Marques APO, Leal MCC, Ramos RSPS, Guerra ACCG, Caldas TM. Adherence to drug therapy in diabetic elderly. Rev Rene. 2013; 14(2):394-404.

21. Almeida HO, Versiani ER, Dias AR, Novaes MRCG, Trindade EMV. Adesão a tratamentos entre idosos. Comun Ciênc Saúde. 2007; 18(1):57-67.

22. Santos ZMSA, Lima HP, Oliveira FB, Vieira JS, Frota NM, Nascimento JC. User's adherence to hypertensive drug therapy. Rev Rene. 2013; 14(1):11-22.

23. Paniz VMV, Fassa AG, Facchini LA, Bertoldi AD, Piccini RX, Tomasi E, et al. Acesso a medicamentos de uso contínuo em adultos e idosos nas regiões Sul e Nordeste do Brasil. Cad Saúde Pública. 2008; 24:267-80.

24. Felipe GF, Moreira TMM, Silva LF, Oliveira ASS. Consulta de enfermagem ao usuário hipertenso acompanhado na atenção básica. Rev Rene. 2011; 12(2):287-94.

25. Sociedade Brasileira de Medicina de Família e Comunidade. Sociedade Brasileira de Clínica Médica. Federação Brasileira das Associações de Ginecologia e Obstetrícia. Sociedade Brasileira de Hansenologia. Associação Médica Brasileira e Conselho Federal de Medicina. Projeto Diretrizes. Aderência a tratamento medicamentoso. [Internet]. 2009 [citado 2010 jun 8]; 8(2): [cerca de 11 p]. Disponível em: http://www. projetodiretrizes.org.br/8_volume/02-Aderencia. pdf 